\title{
Fun Learning Management for Physical Education, Sport and Health
}

\author{
Ramdan Pelana ${ }^{1}$ \\ ${ }^{1}$ Faculty of Sports Sciences, Universitas Negeri Jakarta, Indonesia \\ Correspondence: Ramdan Pelana, Faculty of Sports Science, Universitas Negeri Jakarta, Kampus B, Jl. Pemuda \\ 10, Rawamangun, Jakarta 13220, Indonesia. E-mail: ramdan@unj.ac.id
}

Received: January 16, 2014 Accepted: February 20, 2014 Online Published: February 28, 2014

doi:10.5539/ass.v10n5p85

URL: http://dx.doi.org/10.5539/ass.v10n5p85

\begin{abstract}
Physical education is essentially an integral part of a hollistic education system aims to develop aspects of health, physical fitness, critical thinking skills, emotional stability, social skills, reasoning and moral action through physical activity and sport. In the Physical Education learning process, teachers are expected to teach a variety of basic sports movement skills, techniques and strategies of games and sports, internalization of values (sportsmanship, honesty, cooperation, etc.) and habituation of healthy living. In the lessons, the teacher should provide a variety of approaches so that students are motivated and keen to keep learning. To have the ability to manage learning, teachers need to understand the important elements related to learning management.
\end{abstract}

Keywords: physical education, learning, management, fun

\section{Introduction}

As a profession, teachers are required to have four (4) competencies, i.e pedagogical, personal, social and professional competencies (Law No. 14 of 2005; Regulations of Minister of National Education No. 16 of 2007). Pedagogical competence is defined as the ability to manage the learning of students, while personal competence is the ability to have steady, noble, wise and dignified personalities as well as to become a role model for students. Professional competence is the ability to master the subject matter in a broad and in-depth manner, while social competence is the ability of teachers to communicate and interact effectively and efficiently with students, fellow teachers, parents/guardians of students, and the community. Hence, it is ideal thing for the four competencies to be integrated in the performance of a teacher. Regarding the ability to manage the learning of students (pedagogical competence), teachers must have an interest in learning management. The term management is widely understood as control or arrange. So by doing learning management, teachers basically carry out a process of managing or arranging the learning activities for students.

Physical education is essentially an integral part of an educational system as a whole which aims to develop aspects of health, physical fitness, critical thinking skills, emotional stability, social skills, reasoning and moral action through physical activities and sport. In the learning process of physical education, teachers are expected to teach various skills of basic movement, techniques and strategies of games and sports, the internalization of values (sportsmanship, honesty, cooperation, etc.) as well as the habituation of healthy life. In the implementation of learning, teachers should provide a variety of approaches so that students are motivated and interested in participating with the learning process. To have the ability to manage learning properly, teachers need to understand the important elements related to learning management.

In accordance with the background, the researcher formulate the problem as follows: "What are the essential elements related to the management of learning, especially in the subject of Physical Education, Sport and Health so that the learning process is more enjoyable?" The general goal is to determine the essential elements related to the management of learning in the subject of Physical Education, Sport and Health, allowing the learning process to be more enjoyable, while the special purpose of this article is to identify the task in Physical Education management.

This article is useful for physical education teachers. The learning process in physical education, sport and health requires teachers to have the skills to manage the learning process properly so that the process can go effectively, efficiently and enjoyable for students who participate. This article is also useful for students, so that they can grasp the situation and experiences in a more concrete, meaningful and enjoyable learning environment. 


\section{Literature Review}

\subsection{Definition of Learning Management}

The word management is derived from the Old French word "ménagement", which means the art of implementing and managing. The word management is may also derived from the Italian word "maneggiare" which means "to control," especially "to control a horse", or from the Latin word "manus" which means "hand". This word was then influenced by the French manège which means "a horse ownership" (derived from English, which means the art of controlling a horse). The French then adopted this word from English into ménagement, which means the art of implementing and managing. Management does not have an established definition and is universally accepted. Mary Parker Follett, for example, defines management as the art of completing a job through others. This definition means that a manager is responsible for managing and directing others to achieve organizational goals. Ricky W. Griffin defines management as a process of planning, organizing, coordinating and controlling resources to achieve the objectives (goals) effectively and efficiently. Effectively means that the goals can be achieved in accordance with the planning, while efficiently means that the task at hand is done correctly, organized and in accordance with the schedule. Management functions are the basic elements that will always exist and embedded in management processes that will be used as a reference by managers in carrying out activities to achieve the goals. Management functions can be regarded as the tasks that must be performed by a manager. Management functions were first introduced by a French industrialist named Henry Fayol in the early 20th century. At that time, he mentioned five management functions, namely designing, organizing, commanding, coordinating and controlling. But this time, the five functions have been condensed into four, namely planning, organizing, directing and evaluating.

Planning is thinking about what will be done with the resources that they have. Planning is done to determine the company's overall goals and the best method to meet those goals. Managers evaluate various alternative plans before taking action and then see if the selected plan is suitable and can be used to meet the company's goals. Planning is the most important process of all management functions because without planning, other functions simply cannot go on. The second function is organizing. Organizing is done with the aim of sharing a large activity into smaller activities. Organizing facilitates managers in monitoring and identifying people needed to carry out the tasks that have been divided. Organizing can be done by determining what tasks should be done, who should do them, how the tasks are grouped, who are responsible for the tasks, at which level the decision should be taken. Directing is an action to carry on in order that all members of the group seek to achieve objectives in accordance with the managerial planning and organizational efforts. Hence, actuating means to move people in order that they want to work alone or jointly, while fully aware on how to achieve desired goals effectively. In this case, it takes leadership.

Evaluating is the process of monitoring and controlling the company's performance to ensure that the company runs in accordance with the predetermined plan. A manager is required to find problems that exist in the company's operations, and then solve them before they worsen. Learning, from Gagne in Dahar (1989) can be defined as a process by which an organism changes their behavior as a result of experience. Learning is essentially an activity that expects changes in the behavior of the individual that is learning (National Education, 2004). Degeng in Wena (2009) defines learning as an effort to make students learn. Gagne and Briggs define learning as a series of events (conditions, events, happenings etc.) that are deliberately designed to influence learning, so the learning process can take place easily (National Education, 2004). Learning is not just limited to activities of teachers, just like teaching concepts. Learning includes all activities that may have a direct influence on the learning process of human. Learning also covers events derived by printed materials, pictures, radio programs, television, films, slides or the combination of the materials. Even today, learning occurs with the use of various computer programs, better known as e-learning.

Based on the management and learning concepts, learning management concepts can then be defined as a managing process that includes planning, organizing, controlling (directing) activities and evaluating the activities related to the process to make learners learn by including a variety of factors in order to achieve the goals. In "managing" the learning, managers, in this case teachers, should implement a variety of activities stages ranging from planning the learning, organizing the learning, directing and evaluating the learning. The definition of learning management can thus be interpreted broadly in terms of including the overall activities to make students learn ranging from planning the learning to assessing the learning.

Another opinion states that learning management is part of learning strategies, namely learning management strategies (Made Wena, 2009). Learning management is one of the implementation management of competency-based curriculum (National Education, 2004). Other management includes a human resource 
management, facilities management and assessment management. The factors that need to be considered in terms of learning management are as follows: teacher-student schedules; learning strategies; practice materials management; aid tools management; learning in a group; remedial and enrichment programs; and improving the learning quality. The definition of management above only relates to activities that occur during the interaction process between a teacher and students either both in the classroom or outside the classroom. This definition can be regarded as a learning management concept in a specific case.

Based on the above statements, learning management in a broad sense, contains a managing process of how to make learners learn with activities starting from planning, organizing, directing or controlling and assessing. While learning management in a narrow sense is defined as activities that need to be managed by teachers during the process of interaction with the students in the implementation of learning. This article define learning management in a broad sense. The activities of managing learning from planning, organizing, directing or controlling and assessing needs to be done by a manager (a teacher) with the intention to achieve the desired learning objectives. Management and learning can be distinguished but have the same function. Management emphasizes on aspects of arranging (managing) the learning environment. While learning (instructing), emphasizes on the aspects of managing or processing learning materials. Both of them are used to accomplish the same goals, i.e. the learning goals.

\subsection{Fun Learning}

Before discussing further, perhaps for a teacher, it is familiar when they hear about active, creative, effective and fun learning. Each teacher, in implementing learning, is always expected to apply the active, creative, effective and fun approach. The interpretation of active, creative, effective and fun is that every learning should show more of students' activities (both physical and mental), thus providing greater opportunity for the development of creativity, effectiveness and enjoyable.

The success of active, creative, effective and fun learning lies in the word 'fun'. Fun atmosphere should be developed since the beginning of learning. Dave Meier, in his book The Accelerated Learning Handbook wrote: "Fun or create a learning environment in an atmosphere of joy does not mean to make a fuss or noise. This has nothing to do with reckless pleasure and shallow excitement." Joy here means the rise of interest, the full involvement, as well as the creation of meaning, understanding (mastery over the material being studied) and the value of happiness in the students themselves. Even in the next sentence Meier asserts that the creation of joy is far more important than any method, technique or media used. Another opinion explains that educators or teachers should be able to create a climate of fun learning so that students feel the enjoyment in participating learning activities and it hopes to achieve optimal learning achievement (Walberg \& Greenberg, 1977)

\subsection{Fun Physical Education Learning Management}

Learning management in a broad sense is the overall activities in managing the process of making students learn through the stages of planning, implementation, assessment and control with the intention to achieve the goal of learning itself. Learning management in a narrow sense is managing interaction between teachers and students that occur during the implementation of learning.

Effective learning management can be realized by implementing the following steps: (1) Establishing class rules (class routine). Students who have certain habits acquired from previous life experiences that allow bad habits, as a teacher they need to direct and guide them to do good habits which include establishing class rules at the initial meeting in the learning process performed. For example, in the beginning of the initial meeting teachers should make an agreement with students in which all of them agree and delighted to be in accordance with the collective agreement and the agreement must not be violated. The agreement is like when the lesson starts, be on time and if they are late, they will be punished. And these rules are given at the initial meeting; (2) Starting activities on time (getting started). Activities must start on time according to the initial agreement that has been previously agreed and the students must be present. After students gather, all of them should line up quickly and then does a little pray together. Afterwards, teachers immediately give out stretching instructions and do activities on time so that effective learning takes place; (3) Managing the lesson. After stretching is completed, the teacher should give a little explanation concerning activities about to be practiced. They only give a brief explanation since sport requires practice and moving. Suppose the teacher explains the theory about dribbling in basketball. At first, the teacher will give out a brief explanation, then students are told to immediately put it into practice while in the teacher's company, half of the students do the dribble first while the other half watch, and vice versa. And each student must dribble around the basketball court 3 times; (4) Grouping students. Teachers need to group students equally and must designate a leader in the group, so that the leader should be responsible for the group member's actions. After the students are grouped, equipment are distributed to each group, at first 
they have to see what equipment are available and choose the equipment first before deciding the game. If in one class there are 40 students and 20 balls are available, one class should be divided into 10 groups, to have 4 students in each group including a leader to use 2 balls; (5) Utilizing space or field and equipment. In a basketball lesson, the teacher could divide one class into 6 groups; each group consists of 6 students. Each group must compete dribbling the ball from one area to the next, if one group comes in last, they will get 5 times push-ups punishment; (6) Ending a lesson. About 15 minutes before the lesson ends, the teacher should give an evaluation about the lesson given. It doesn't have to be long, 5 minutes is sufficient, and then allow students to take a break and change clothes at the remaining 10 minutes.

\section{Learning Management}

To support the learning process, then the learning management elements should include two measures, namely:

a. Action model

1) Preventive, i.e. early efforts made by teachers to prevent interference in the learning. (1) Responsive/sensitive, i.e. the ability of teachers to respond to the behaviors or activities that are considered to interfere the learning. (2) Close attention, always pay attention for the various activities, the environment and everything that appears.

2) Repressive, i.e. the ability of teachers to cope, seek and find the right solution to solve the problems that occur in the environment of learning.

3) Modification of behavior, i.e the behavior that can be observed: (1) Group management, i.e. to deal with problems should be done in collaboration and include a variety of relevant components or elements. (2) Diagnosis, i.e. a skill to find elements that would be the cause of the interference as well as the elements that will be a force for improvement the learning process.

\section{b. Role of teachers.}

In this case, teachers have a role to: (1) Encourage students to develop individual's responsibility towards the environment; (2) Develop students' understanding to comprehend and adapt their behavior to the class discipline;

(3) Create a sense of obligation to involve in tasks as well as the behavior in accordance with class activities.

c. Things that should be avoided.

The things that should be avoided include: 1) excessive interference, 2) silence, 3) inaccuracy, 4) deviations, 5) rambling.

\section{Fun Learning Techniques}

One of the factors that influence the success of an education is determined by how the learning process takes place. Besides, the interaction process of studying principally depends on teachers and students. Teachers are required to create an effective learning environment. Meanwhile, students are demanded to have the passion and drive to be active in the process of teaching and learning. So the success of learning in the areas of cognitive, affective and psychomotor can be achieved. Meier states that "the creation of joy is far more important than any method, technique or media used", we find fun atmosphere building components. The components are (1) rise of interest, (2) full involvement, (3) creation of sense, (4) understanding or mastery of materials, and (5) values of happiness. To better understand the important issues related to fun learning, the following are the fun atmosphere building components.

\section{a. Rise of interest.}

As we know, interest is something to do with the will or desire. Interest is also often paired with passion or strong desire. Now try to connect the 'rise of interest' with the 'joy'. If students have early interest or passion to learn something, surely it would be a fun learning experience for the students. So the relationship between interest or passion and fun are very close and influence each other. If the interest in learning has grown, then the desire to learn will create passion and the atmosphere will be more fun. Fun atmosphere maintained throughout the learning process will affect the learning passion during the ongoing learning.

b. Full involvement.

This component is dependent on the first component. Example, a student may not engage wholeheartedly in learning if within the student have no passion or strong interest in keeping up with the lesson. Thus, there must be a strong relationship between who will learn and what will be learned. In order that students are passionate and fully engaged in learning, teachers needs to deliver learning objectives clearly and in detailed in the beginning of learning. Tell the students that what they will learn is something that is very important, easy and will be learned in a fun way. Purposefully explain what will be done in class to the students in order for students 
to be psychologically prepared.

c. Creation of sense.

The definition of sense here is not in the general context that is often paired with the word 'meaning'. Sense is not easy to define because it is closely related to each individual and sometimes appears very strong in a personal context. In active, creative, effective and fun context of learning, the word 'sense' is closer to the definition of 'impression'. It means impressive learning To create a sense, learning must be impressive. Later, in order that learning can be impressive then it must be done in a fun atmosphere. Because 'sense' often appears in a very personal context, then teachers must truly understand and appreciate individual differences of each student.

d. Understanding or mastery of materials

When learning interest or passion of a student grows, then he/she is fully engaged in studying the learning materials, and later if he/she is impressed with what is learned, as a result, an understanding of what is learned will be firmly entrenched. Mastery of the materials will be strongly embedded if students are interested, engaged and impressed.

e. Values of happiness.

Happiness means to make hearts feel tranquil. Tranquil hearts are those that are free from fear, depressed and far from feeling threatened. In relation with learning, happy is a state free from depression, fear and threats. Feelings of fear, depressed and threatened will not emerge and haunt students' feelings when learning is done in a fun atmosphere. The three feelings (fear, depressed and threatened) will only be an obstacle to the onset of learning interest. The feeling of happiness on students, among others, can emerge as he/she gains the sense of learning something. He/she will feel more valuable, capable of growing and evolving and becoming different from before. When a student is able to solve problems in the learning process, within him/her will be a sense of pride and confidence. That sense of pride and confidence will make students realize that he/she has the potential as others do. Thus, in order to help students achieve values of happiness in the learning process, teachers must strive constantly to help foster the sense of pride and confidence in each student.

\section{Conclusion}

Learning means to build student's learning experience with a variety of process skills to gain new experience and knowledge. Fun is meant in order that teachers are able to create a fun learning environment so that students are fully focused. Fun learning is an attempt to build students' learning experience with a variety of process skills to gain new experience and knowledge, through the creation of a variety of learning activities and learning atmosphere condition so as to provide services at different levels of abilities and learning styles of students, and the students are focused to their full potential. Learning environment needs to be designed properly by teachers to grow the student's interest in learning. The creation of learning environment is the first step for teachers to facilitate their students to learn. A conducive learning atmosphere allows students' imagination and creativity to flourish. Diverse backgrounds of students can be a good input in the classroom if they are managed correctly. Management of students based on groups of thinking skill, action skill and other skills is designed by teachers in a classroom management: (a) Learning planning, assessment and learning management; (b) Remember to determine success in learning activities; (c) While as the building elements on the achievement of learning management are the action model, the active role of teachers and the avoidance of things that are considered less necessary in managing learning, especially in the subject of Physical Education, Sport and Health.

\section{References}

Nurhadi. (2002). Pendekatan Kontekstual (Contextual Teaching and Learning (CTL)). Jakarta: Depdiknas.

Suherman, A. (2001). Asesmen Balajar dalam Pendidikan Jasmani Evaluasi Alternatif untuk Sekolah Lanjutan Tingkat Pertama. Jakarta: Depdiknas.

Syarifudin. (1998). Pokok-Pokok Pengembangan Program Pembelajaran Pendidikan Jasmani. Jakarta: Depdikbud.

Umaedi. (1999). Manajemen Peningkatan Mutu Berbasis Sekolah Sebuah Pendekatan Baru Dalam Pengelolaan Sekolah untuk Peningkatan Mutu. Jakarta: Depdikbud. 


\section{Copyrights}

Copyright for this article is retained by the author(s), with first publication rights granted to the journal.

This is an open-access article distributed under the terms and conditions of the Creative Commons Attribution license (http://creativecommons.org/licenses/by/3.0/). 